\title{
Dijital Bağımlılık ve FoMo, Kişilik Faktörleri ve Mutluluk ile illişkisi: Üniversite Öğrencileri ìle Bir Uygulama
}

\section{Digital Addiction and Relationship between FoMo, Personality Factors and Happiness: An Application in University Students}

\author{
Hande Sarıca Keçeci ${ }^{1}$ (D), Esra Kâhya Özyirmidokuz 2 ${ }^{\text {(D) }}$, Lale Özbakır ${ }^{3}$ (D) \\ 1. Erciyes Üniversitesi Yönetim Bilișim Sistemleri Anabilim Dalı, Kayseri \\ 2. $\quad$ Erciyes Üniversitesi İktisadi İdari Bilimler Fakültesi Işsetme Bölümü, Kayseri \\ 3. Erciyes Üniversitesi Mühendislik Fakültesi Endüstri Mühendisliği Bölümü, Kayseri
}

\section{Abstract}

Objective: This research explores the relationships between social media addiction, smartphone addiction, gaming disorder and personality, fear of missing out on developments (FoMo) and happiness.

Method: This study was conducted with 497 volunteer participants (61,2\% female, 38,8\% male) who were Erciyes University students. The questionnaire consists of Five- Factor Personality Scale, Uskudar Fear of Missing Out Scale, Smartphone Addiction Scale (SAS), Internet Gaming Disorder Scale (IGDS9-SF), Social Media Addiction Scale (SMAS-SF), Toronto Alexithymia Scale and Oxford Happiness Scale.

Results: There is a significant correlation between mobile addiction, gaming disorder, FoMo and social media addiction Neuroticism, agreeableness and conscientiousness with mobile addiction were correlated with gaming disorder. Significant relationships were found between social media addiction and neuroticism; virtual communication and virtual problem with conscientiousness and also between virtual knowledge and extraversion.

Conclusion: It was determined there are prominent relationships between factors of social media addiction, smartphone addiction, game-playing disorder, personality traits, fear of missing out (FoMo) and happiness.

Keywords: Digital addiction, personality, fear of missing out, happiness

Öz

Amaç: Bu çalışmada sosyal medya bağımlıı̆̆ı, akıllı telefon bağımlılı̆ı, oyun oynama bozukluğu ile kişilik, gelişmeleri kaçırma korkusu (FoMo) ve mutluluk arasındaki ilişkilerinin araştırıması amaçlanmıştır.

Yöntem: Erciyes Üniversitesi'nde 497 gönüllü katılımcıya (\%61,2 kadın, \%38,8 erkek) Beş Faktör Kişilik Ölçeği, Üsküdar Eksik Olma Korkusu Ölçeği, Akıllı Telefon Bağımlılığı Ölçeği (SAS), İnternet Oyun Oynama Bozukluğu Ölçeği (IGDS9-SF), Sosyal Medya Bağımlılığı Ölçeği (SMAS-SF), Toronto Aleksimi Ölçeği ve Oxford Mutluluk Ölçeği uygulanmışıtır

Bulgular: Mobil bağımlık, oyun oynama bozukluğu ve FoMo ile sosyal medya bağımlılı̆ı arasında anlamll; mobil bağımlılık ile nevrotiklik, yumuşak başlılık ve dürüstlük arasında anlamlı; oyun oynama bozukluğu ile yumuşak başılıık ve dürüstlük arasında anlamlı ilişkiler bulunmuștur. Sosyal medya bağımılıı̆ı ile nevrotiklik arasında; sanal iletişim ve sanal problem ile dürüstlük arasında; sanal bilgi ile dışadönüklük arasında anlamlı ilişkiler bulunmuştur. Sonuç: Bu araştırma sonucunda, sosyal medya bağımlılı̆ı, akıllı telefon bağımlıı̆ı, oyun oynama bozukluğu ile kişilik, FoMo ve mutluluk arasında ilişkiler tespit edilmiştir.

Anahtar kelimeler: Dijital bağımlıık, kişilik, gelişmeleri kaçırma korkusu, mutluluk 


\section{Giriş}

Dijitalleşen dünyanın getirisi ve bir parçası olarak birçok insan dijital cihazlarla sürekli etkileşim içerisindedir. Teknolojinin gelişimi, tüm işlemlerimizi saniyeler içerisinde cep telefonlarından yapabiliyor oluşumuz, özellikle dünyada yaşanan son gelişmeler neticesinde insanların iletişim yolu olarak gerek mecburi gerek istemli internet ortamını tercih ediyor oluşu; dijital bağımlıı̆ın doğmasına zemin hazırlamaktadır. Sosyal medya, cep telefonları, teknolojik cihazlar hayatımızın birer parçası olmuştur. Covid-19 Pandemi sürecinde sanal boyut gerçek dünya kadar önemli hale gelmiştir.

Türkiye İstatistik Kurumu'nun Hane-halkı Bilişim Teknolojileri Kullanım Araştırması'na göre internet kullanım oranı 2020 yılında 16-74 yaş grubundaki bireylerde \%79,0 oranındadır. Bu oran, bir önceki yıl $\% 75,3$ 'tür. İnternet kullanım oranı cinsiyete göre incelendiğinde; bu oranın erkeklerde \%84,7, kadınlarda \%73,3 olduğu görülmektedir (1). Türkiye'de internet kullanıcı sayısı toplamda 62 milyon, Türkiye nüfusunun \%74'ü oranındadır (2). UNICEF 2017 yılında "Dünya Çocuklarının Durumu" başlıklı yayınladığı raporda Dijital Teknoloji konusu üzerinde durmuştur. 18 yaşından küçük çocuklar ve ergenler (Dünya Sağlık Örgütü, 11-18 yaş aralığındaki bireyleri ergen olarak nitelendirilmektedir) tüm dünyadaki internet kullanıcılarının üçte birini oluşturmaktadır (3).

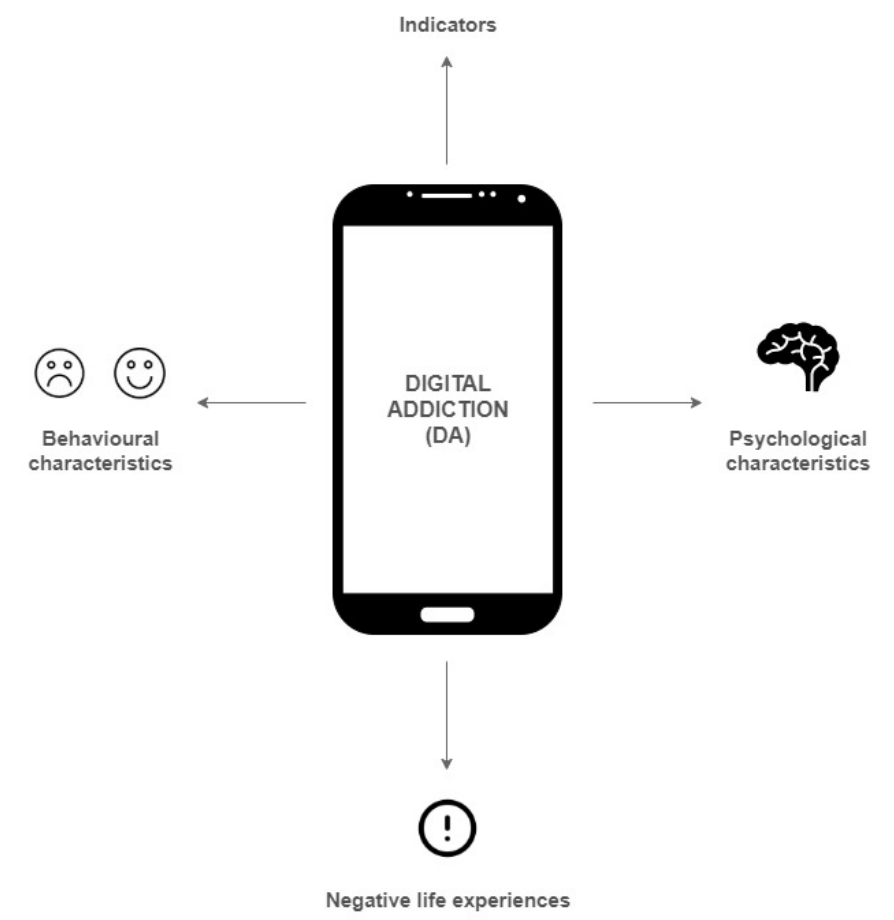

\section{Şekil 1. Dijital bağımlılık modeli}

Dijital cihazlar ve sosyal ağların uzun süre ve bilinçsiz kullanımları neticesinde hem yetişkinler hem de çocuklar ve gençler gerek fiziksel gerek ruhsal açıdan olumsuz etkilenmelerine neden olmaktadır. Görülebilecek rahatsızıkların başında bağımlılık kavramı gelmektedir. Yapılan çalışmalar internet ve dijjtal cihazların kullanımının daha küçük yaşlardan itibaren görülebileceğinin yanı sıra mobil cihazlarda ve sosyal ağlarda geçirilen sürenin gün geçtikçe artış gösterdiği yönündedir. Illetişim araçlarının dijitalleşmesi ve yaşanan teknolojik değişimler neticesinde; yanı sıra sorunlu ve aşıı sosyal ağ kullanımı sebebiyle davranışsal bir bağımlılık türü olarak ele alınan DiB (Dijital Bağımlıık) kavramı ortaya çıkmıştır (4). DiB; zorlayıcı, dürtüsel, aşırı ve aceleci olma gibi özelliklerle karakterize edilen dijital cihazların sorunlu kullanımını ifade eder (5).

Gelişen dijital yazıımlar sonucunda teknoloji temelli; internet bağımlılı̆ı, oyun bağımlı̆ı̆ı, akılı telefon bağımlılığı ve sosyal medya bağımlılı̆ı gibi yeni tip davranışla ilgili bağımlılıklar ortaya çıkmıştır (6). 
Amerikan Psikiyatri Birliği tarafından yayımlanan Ruhsal Bozuklukların Tanısal ve istatistiksel El Kitabı-5 (DSM-5)'te DiB, internet bağımlılığı, akıllı telefon bağımlıı̆ı ve sosyal medya bağımlılığı ruhsal bozukluk olarak sınıflandırımamaktadır ancak DSM-5'in üçüncü bölümünde oyun bağımlılı̆ı kavramı "internet oyun oynama bozukluğu" (I0OB) olarak tanımlanmıştır ve üzerinde daha fazla araştırma yapılması tavsiye edilmiştir (7). İnternet bağımlığı, teknolojiye yönelik bağımlııklar arasında ilk olarak tanımlanan ve kriterleri belirlenen bağımlılık türüdür (8). Zaman içerisinde oyun bağımlıı̆̆ı, akıllı telefon bağımlılığı ve sosyal medya bağımlılı̆ı da literatürde yer alımıştır. Son yıllarda hastanelerde bağımlılık poliklinik servislerinin açılıyor olması da DiB kavramının bireyler için artan bir sorun olduğunun göstergesidir.

DiB kavramının tanımı ile ilgili fikir birliği eksikliği sonucuna varımış ve bu tanımlar arası tespit edilen; olgunun neden olduğu zarar odaklı veya kullanıcının davranışlarına odaklı çerçevesinde farklar ortaya konulmuştur (9). Dr. Raian Ali, dijital bağımlı̆̆ğı saplantılı, aşırı uçlarda, zorlayıcı, düşünmeden yapılan ve aceleci davranışsal bağımlıık belirtilerini içeren problemli teknoloji kullanımı şeklinde tanımlamaktadır. DiB, kavramsal model yapısı olarak Şekil 1'de Dr. Raian Ali ve araştırma ekibi tarafından sunulan DiB modeli çerçevesinde değerlendirilmektedir (10).

DiB tüm dünyada üzerine araştırmalar yürütülen ve son yıllarda farklı araştırma konularında yer alan önemli bir kavram haline gelmiştir (11-17). Türkiye'de DiB kavramı ile ilgili yapılan araştırmalarda ölçek geliştirme çalışmaları olduğu görülmektedir (18-20). DiB kavramı (21-24), teknoloji bağımlı̆̆ğı (25), internet bağımlılığı (26), sosyal ağlarda DiB (4) gibi konularda yapılan çalışmalar mevcuttur. Ülkemizde oyun bağımlılığı üzerine yapılan çalışmalar; oyun bağımlıı̆̆ının farklı yaş gruplarına olan etkisi (27-31), psikolojik faktörler $(32-37)$ ve sporun etkisi $(38,39)$ gibi konuları kapsamaktadır. Ayrıca son yıllarda teknoloji bağımlıı̆̆ı, internet bağımlılı̆ı, sosyal medya bağımlıı̆̆, akıllı telefon bağımlılığı ve dijital oyun bağımlılı̆ı gibi bağımlıık türlerini, farklı bağımlılık türleri ile araştıran çalışmalar artış göstermiştir (40-44).

Dijital cihazların ve sosyal medyanın aşırı kullanımı sonucu ortaya çıkan kavramlardan birisi de Türkçe 'de "Gelişmeleri Kaçırma Korkusu" olarak çevrilen FoMo (Fear of Missing Out) kavramıdır (45-47). Sosyal medyaya sorunlu bağlanmanın temel bir türü olarak, sosyal medya bağımılı̆̆ının temel sebeplerinden birisi olarak FoMo ileri sürülmektedir (48). FoMo'nun bireylerde görülen etkileri yaşam yeterliliğinin azalması, duygusal gerginlik, fiziksel refah üzerindeki olumsuz etkiler, anksiyete ve duygusal kontrol eksikliğidir (49, 50). Birçok çalışma FoMo'yu psikolojik açıdan (51-53) ele alsa da bağımlıık ile ilgili yapılan çalışmalar da mevcuttur $(45,50,54)$.

Literatürde, Şekil 2'de verilen DiB'i kavramsal çerçevede inceleyen ve Türk öğrencileri ile sosyal medya bağımlılı̆ı, akıllı telefon bağımlılı̆ı ve oyun oynama bozukluğu ile FoMo, mutluluk ve kişilik faktörlerinin ilişkilerini araştıran bir çalışma bildiğimiz kadarıyla yoktur. Bu çalışmanın amacı sosyal medya bağımlıı̆ı, akıllı telefon bağımlılı̆ı, oyun oynama bozukluğu ile beş faktör kişilik özellikleri, FoMo ve mutluluk arasındaki ilişkiyi keşfetmektir. Çalışma, DiB ile mücadele için katkı sağlama hedefindedir.

\section{Yöntem}

\section{Örneklem}

Erciyes Üniversitesi'nde öğrenim gören 507 katılımcıdan çevrimiçi ortamda 2019 yılı Nisan, Mayıs, Haziran ayları boyunca toplanan veri üzerinde gerçekleştirilmiştir. Araştırmada tesadüfi olmayan örneklem yöntemlerinden, kolayda örneklem yöntemi seçilmiştir. Son belirlenen katııımcı sayısı 497 (304 kadın, 193 erkek)'dir. Toronto Aleksimi ve Oxford mutluluk testine katılımcı sayısı 461 olup, beş faktör kissilik testi, FoMo testi, mobil bağımlılık testi ve sosyal medya bağımlılık testi katılımcı sayısı 497 dir. Ayrıca oyun oynama bozukluğu testi ankette seçmeli olarak katılımcılara sorulması nedeniyle bu test 224 katılımcı tarafından cevaplanmıştır.

\section{İşlem}

Bu çalışma, 01.11.2017-1.11.2020 tarihleri arasında yürürlükte olan 116E676 numaralı Tübitak 1003 
Öncelikli Alanlar Ar-Ge projesi kapsamında yürütülmüştür. Erciyes Üniversitesi Sosyal ve Beşeri Bilimler Etik Kurulu'ndan alınan etik kurul raporu Tübitak proje başvurusu ile alınmıştır. Yapılan araştırmalar proje raporunda mevcuttur. Anket çalışması projenin devam ettiği 2019 senesinde yapılmış olup, katılımcılar gönüllülük esası ile çalışmaya katılmışlardır.

\section{Veri Toplama Araçları}

Veri toplama aracı olarak, Google Forms üzerinden çevrim içi uygulanan anket; ortalama 60 dakika süre ile sınıf ortamında katılımcılar tarafından doldurulmuştur. 5'li Likert tipi anket yöntemi kullanılmıştır (1=Kesinlikle Katımıyorum, 5=Kesinlikle Katılıyorum). Katılımcılara önce sosyal medya kullanım durumları, oyun oynayıp oynamadıkları, akıllı bir cihaz veya cep telefonu kullanıp kullanmadıkları sorulmuştur. Ankette sorulan yaş, cinsiyet demografik değişkenleri hipotezlerde kullanılmamış betimleyici istatistik bilgisi olarak incelenmiştir.

Ankette kullanılan ölçekler Türkiye'de geçerlik ve güvenilirlik analizleri yapılan çalışmalardır. Beş Faktör Kişilik Ölçeği, Üsküdar Gelişmeleri Kaçırma Korkusu Ölçeği, Mobil Bağımllık Ölçeği, Oyun Oynama Bozukluğu Ölçeği, Sosyal Medya Bağımlılık Ölçeği tercih edilmiş olup yanı sıra 3 faktörden oluşan Toronto Aleksimi Ölçeği ile duygularının farkındalıkları tespit edilmiştir. Oxford Mutluluk Ölçeği ile mutluluk ölçümü yapılmıştır.

\section{Beş Faktör Kişilik Ölçeği}

Beş faktör kişilik değerlendirmesi için, Yoo ve Gretzel tarafından geliştirilen 5 faktörden oluşan kişilik anketi kullanılmıştır (55). Uyar tarafından anketin Türkçe formu hazırlanmıştır (56). Ölçek 25 madde ve 5 alt boyuttan oluşmaktadır. Bu alt boyutlar şunlardır: Nevrotiklik, dışa dönüklük, deneyime açıklık, yumuşak başlılık, dürüstlük. Ölçeğin Cronbach's alfa değerleri her bir alt madde için 0,718 ile 0,874 değerleri aralığında bulunmuştur.

\section{Üsküdar Gelişmeleri Kaçırma Korkusu Ölçeği}

Metin vd. tarafından geliştirilen Üsküdar Gelişmeleri Kaçırma Korkusu Ölçeği FoMo düzeyi belirlemede tercih edilmiştir (57). Ölçek 31 madde ile hazırlanıp sonrasında 22 madde olarak güncellenmiştir. Ölçeğin iki maddesi ters ifade içermektedir. Geçerlik ve güvenilirlik çalışması yapılan ölçekte; Cronbach's alfa değeri 0,88 olarak bulunmuştur. Yapılan madde-toplam korelasyon testi sonucu 0,40 ile 0,73 arasında değerler tespit edilmiştir.

\section{Mobil Bağımlılık Ölçeği}

Kwon vd. (58)'nin geliştirdiği Akıllı Telefon Bağımlıı̆ı Ölçeği'nin Türkçe uyarlaması (59) kullanılmıştır. Ölçek 33 maddeden oluşmaktadır. Çalışmanın orijinalinde 0,967 olarak bulunan Cronbach's alfa değeri, Türkçe geçerliği yapılan bu çalışmada 0,947 olarak bulunmuştur.

\section{Oyun Oynama Bozukluğu Ölçeği}

Pontes ve Griffiths tarafından (60) geliştirilen ve Arıcak vd. tarafından (61) Türkçe 'ye uyarlanan Internet Oyun Oynama Bozukluğu Ölçeği Kısa Formu (IGDS9-SF-TR) 'nun geçerlik ve güvenilirlik çalısması yapılmıştır. Ölçeğin kısa formu 9 sorudan oluşmaktadır. Çalışmanın orijinali 58 farklı ülkede gerçekleştirilip, DSM-5 tanı kriterlerine dayandırımıştır. Tavan ve taban etkisi tüm maddelerde incelenerek etkisi gözlenmiştir. Ölçeğin Cronbach's alfa değeri 0,82 ve Guttman yarı yarıya güvenilirlik analizi değeri 0,75 olarak bulunmuştur.

\section{Sosyal Medya Bağımllık Ölçeği}

Şahin tarafından (62) geliştirilen Sosyal Medya Bağımlılığı Ölçeği Öğrenci Formu (SMA-SF) 29 madde ve 4 alt boyuttan oluşmaktadır. Alt boyutlar ve ait olduğu soru miktarları şu şekildedir: 5 soru sanal tolerans, 9 soru sanal iletişim, 9 soru sanal problem ve 6 soru sanal bilgi. Ölçeğin Cronbach's alfa değerleri her bir alt madde için 0,81 ile 0,86 değerleri aralığında bulunup, totaldeki Cronbach's alfa değeri 0,93'tür. 


\section{Toronto Aleksitimi Ölçeği}

Bagby ve arkadaşları tarafından (63) geliştirilen ve Güleç ve arkadaşları tarafından (64) Türkçe‘ye uyarlanan Toronto Aleksitimi Ölçeği (TAÖ)' nin geçerlik ve güvenilirlik çalışması yapılmıştır. Çalışmanın orijinali 20 madde ve 3 alt boyuttan oluşmaktadır. Alt boyutlar ve ait olduğu soru miktarları şu şekildedir: 7 soru duyguları tanımada zorluk, 5 soru duyguları tanımlamada zorluk, 8 soru dış odaklı düşünme. TAS-20 ölçeğinin Cronbach's alfa değerleri her bir alt madde için 0,57 ile 0,80 değerleri aralığında bulunup, totaldeki Cronbach's alfa değeri 0,78'tir.

\section{Mutluluk Ölçeği}

Oxford Mutluluk Ölçeği Hills ve Argyle (65) tarafından geliştirilmiştir. Geçerlik ve güvenilirliği yapılan Oxford Mutluluk Ölçeği Türkçe versiyonu (66) sübjektif (öznel) mutluluk ölçüm düzeyi belirlemek amacıyla kullanılmıştır. Toplamda 29 maddenin 12 maddesi ters ifade içermektedir. Ölçeğe ait faktör yükleri 0,32 ile 0,77 arasındadır. Cronbach's alfa iç tutarlıık katsayısı 0,91 , test yarılama yöntemi sonucu güvenilirlik katsayısı 0,86 ve bileşik güvenilirlik sonucu 0,91 olarak bulunmuştur.

Tablo 1. Faktörlere ait hipotez denklemleri

\begin{tabular}{|c|c|c|}
\hline Hipotez & Ölçek (Test) & $\begin{array}{l}\text { Isslem (Her bir } \\
\text { faktör ile ilişki) }\end{array}$ \\
\hline $\begin{array}{l}\text { H0: Katılımcıların kişilik } \\
\text { faktörlerinden } x^{*} \text { tipi ile } y^{\star \star} \text { tipi } \\
\text { arasında anlamlı bir ilişki yoktur. }\end{array}$ & $\begin{array}{l}\text { Beş faktör kişilik } \\
\rho \\
\text { Mobil bağımlılık/ Oyun oynama bozukluğu/ FoMo/ } \\
\text { Mutluluk }\end{array}$ & $\mathrm{x}^{\star} \rho \mathrm{y}^{\star \star}$ \\
\hline $\begin{array}{l}\text { H1: Katılımcıların sosyal medya } \\
\text { bağımlılığı faktörlerinden } z^{\star \star \star} \text { tipi } \\
\text { ile } \mathrm{y}^{\star \star} \text { tipi arasında anlamlı bir } \\
\text { ilişki yoktur. }\end{array}$ & $\begin{array}{l}\text { Sosyal medya bağımlılı̆̆ı } \\
\rho \\
\text { Mobil bağımlılık/ Oyun oynama bozukluğu/ FoMo/ } \\
\text { Mutluluk }\end{array}$ & $\mathrm{Z}^{\star \star \star} \rho \mathrm{y}^{\star \star}$ \\
\hline $\begin{array}{l}\text { H2: Katılımcıların kişilik } \\
\text { faktörlerinden } x^{\star} \text { tipi ile } z^{\star * \star} \text { tipi } \\
\text { arasında anlamlı bir ilişki yoktur. }\end{array}$ & $\begin{array}{l}\text { Beş faktör kişilik } \\
\rho \\
\text { Sosyal medya bağımlıı̆ı̆ı }\end{array}$ & $x^{\star} \rho z^{* \star \star}$ \\
\hline $\begin{array}{l}\text { H3: Katılımcıların }{ }^{\star \star \star \star \star} \text { tipi ile } y^{\star \star} \\
\text { tipi arasında anlamlı bir ilişki } \\
\text { yoktur. }\end{array}$ & $\begin{array}{l}\text { Mobil bağımlılık/ Oyun oynama bozukluğu/ FoMo/ } \\
\text { Mutluluk } \\
\rho \\
\text { Mobil bağımlılık/ Oyun oynama bozukluğu/ FoMo/ } \\
\text { Mutluluk }\end{array}$ & $\mathrm{t}^{\star \star \star \star} \rho \mathrm{y}^{\star \star}$ \\
\hline
\end{tabular}

$\mathrm{X}^{\star}$ = Nevrotiklik, dışadönüklük, açık fikirlilik, yumuşak başlıık ve dürüstlük

$\mathrm{y}^{\star \star}=$ Mobil bağımlılık, oyun oynama bozukluğu, FoMo ve mutluluk

$\mathrm{Z}^{\star \star \star}=$ Sanal tolerans, sanal iletişim, sanal problem, sanal bilgi

$t^{\star \star \star \star}=$ Mobil bağımlılık, oyun oynama bozukluğu, FoMo ve mutluluk

\section{Veri Analizi}

Çalışmada istatistiksel analizler yapıımıştır. Yapılan ön analizde Toronto Aleksimi Ölçeği ortalama değerleri incelenerek belirlenen değerin altında kalan katılımcılar örneklemden çıkarılmıştır. Yanı sıra aykııı değerlerin tespitinde Mahalanobis mesafeleri hesaplanarak veri setindeki en yüksek ve en düşük uç değer örneklemden kaldırımıştır. Böylece son katıımcı sayısı 497 olarak belirlenmiştir. Toronto Aleksimi Ölçeği katıımcıların duygularının farkında olup olmadıklarını belirlemek amacıyla kullanılmışıı. Duygu farkındalıkları olan katılımcılar ile analizler yapılmıştır. Kullanılan ölçeklerin güvenilirliğinin tespitinde Cronbach's alfa yöntemi kullanılmıştır. Cronbach's alfa değeri 0,70 ve üzerinde olan ölçekler güvenilir kabul edilmektedir (67).

Çarpıklık-basıklık değeri -2 ile +2 aralığında olan veriler normal dağılım göstermektedir (68). Verilerin 
dağılımı Kolmogorov-Smirnov testi ile değerlendirilmiştir. Ölçekler arasında anlamlı bir ilişki olup olmadığına korelasyon analizi yapılarak karar verilmişsir. Veriler normal dağılıma sahip olduğu için, korelasyon ilişkisinde Pearson korelasyon testi uygulanmıştır. Beş faktör kişilik özellikleri, FoMo ve mutluluk ile DiB arasındaki ilişkiyi keşfedebilmek için Tablo 1'de verilen hipotezler geliştirilmiş ve bu hipotezler çerçevesinde analizler yapılmıştır.

\section{Bulgular}

Katılımcıların demografik bilgilerine göre; katılımcılardan 304'ü $(\% 61,2)$ kadın, 193'ü $(\% 38,8)$ erkektir. Katılımcılardan ikisi yaş değişkenine cevap vermemişsir. Verilerin normal dağlım gösterip göstermediğini incelemek amacıyla Kolmogorov-Smirnov testi uygulanmıştır. Tablo 2'de ölçeklerin minimum-maksimum ve çarpıklık-basıklık değerleri verilmiştir. Bu değerlere göre verilerin normal dağılım gösterdikleri söylenebilir $(p<0,05)$.

\section{Tablo 2. Ölçeklerin normallik testi sonuçları}

\begin{tabular}{|c|c|c|c|c|}
\hline & Minimum & Maksimum & Çarpıklık & Basıklık \\
\hline \multicolumn{5}{|l|}{ Beş Faktör Kişilik Ölçeği } \\
\hline Nevrotiklik & 1,00 & 5,00 & $-0,099$ & $-0,539$ \\
\hline Dışadönüklük & 1,20 & 5,00 & $-0,171$ & $-0,678$ \\
\hline Açık fikirlilik & 1,20 & 5,00 & $-1,143$ & 1,604 \\
\hline Yumuşak başlılık & 1,20 & 5,00 & $-0,555$ & 0,685 \\
\hline Dürüstlük & 1,20 & 5,00 & $-0,292$ & $-0,241$ \\
\hline FoMo Ölçeği & 1,00 & 4,77 & 0,397 & $-0,621$ \\
\hline Mutluluk Ölçeği & 1,24 & 4,79 & $-0,343$ & 0,032 \\
\hline Mobil Bağımlılık Ölçeği & 1,00 & 4,55 & 0,770 & 0,398 \\
\hline \multicolumn{5}{|l|}{ Sosyal Medya Ölçeği } \\
\hline Sanal Tolerans & 1,00 & 5,00 & 0,404 & $-0,440$ \\
\hline Sanal İletişim & 1,00 & 4,67 & 0,833 & 0,687 \\
\hline Sanal Problem & 1,00 & 4,56 & 1,075 & 0,946 \\
\hline Sanal Bilgi & 1,00 & 5,00 & 0,007 & $-0,444$ \\
\hline Oyun Oynama Bozukluğu Ölcceği & 1,00 & 4,78 & 0,833 & 0,273 \\
\hline
\end{tabular}

Tablo 3. Ölçeklerin iç tutarlılık güvenilirlik sonuçları

\begin{tabular}{|c|c|c|c|}
\hline Ölçekler & Ortalama & Standart Sapma & Cronbach's Alfa \\
\hline \multicolumn{4}{|l|}{ Beş Faktör Kişilik Ölçeği } \\
\hline Nevrotiklik & 3,29 & 0,927 & 0,823 \\
\hline Dişa Dönüklük & 3,37 & 0,898 & 0,814 \\
\hline Açı Fikirlilikik & 4,28 & 0,665 & 0,809 \\
\hline Yumuşak Başllık & 3,68 & 0,659 & 0,683 \\
\hline Dürüstlük & 3,72 & 0,709 & 0,786 \\
\hline FoMo Ölçeği & 2,42 & 0,810 & 0,931 \\
\hline Mutluluk Ôlçeği & 3,41 & 0,607 & 0,906 \\
\hline Toronto Aleksimi Ölçeği & 2,69 & 0,523 & 0,762 \\
\hline Mobil Bağımlılık Ölçeği & 2,11 & 0,633 & 0,930 \\
\hline \multicolumn{4}{|l|}{ Sosyal Medya Bağımlilığı Ölçeği } \\
\hline Sanal Tolerans & 2,53 & 0,972 & 0,832 \\
\hline Sanal Illetişim & 1,99 & 0,696 & 0,817 \\
\hline Sanal Problem & 1,78 & 0,703 & 0,855 \\
\hline Sanal Bilqi & 2,68 & 0,884 & 0,807 \\
\hline Oyun Oynama Bozukluğu Ölçeği & 2,14 & 0,845 & 0,867 \\
\hline
\end{tabular}

Ölçeklerin güvenilirlik tespitinde Cronbach's alfa yöntemi kullanıımıştr. Tablo 3'te ölçeklerin ortalama ve standart sapma değerleri ile Cronbach's alfa değerleri yer almaktadır. Alt maddelere sahip ölçekler 
belirtilmiştir. Cronbach's alfa değerleri incelendiğinde ölçeklerin güvenilir oldukları söylenebilir. FoMo ölçeği, Cronbach's alfa değeri 0,931 ile en yüksek güvenilirlik değerine sahiptir.

Tablo 4'te sosyal medya bağımlılık faktörleri ile mobil bağımlıık, oyun oynama bozukluğu, FoMo ve mutluluk arasındaki korelasyon değerleri verilmektedir. Korelasyon değerlerinin \%1 ya da \%5 düzeyindeki anlamlılığı ve oluşan ilişkilerin pozitif ya da negatif yönlülüğü görülmektedir. Mobil bağımlık ile tüm sosyal medya bağımlıı̆̆ faktörleri arasında istatistiksel olarak anlamlı güçlü ve pozitif yönde ilişkilere (sanal tolerans, $r=0,716$; sanal iletişim, $r=0,685$; sanal problem, $r=0,729$; sanal bilgi, $r=0,535$ ) rastlanmıștır $(p<0,01)$. Sosyal medya bağımlıık faktörleri arttıkça mobil bağımılı̆ğın da artacağı söylenebilir. FoMo ile tüm sosyal medya bağımlılığı faktörleri arasında istatistiksel olarak anlamlı nispeten güçlü ve pozitif yönde ilişkilere (sanal tolerans, $r=0,530$; sanal iletişim, $r=0,516$; sanal problem, $r=0,589$; sanal bilgi, $r=0,580$ ) rastlanmışıı $(p<0,01)$. Oyun oynama bozukluğu ile tüm sosyal medya bağımlılı̆ı faktörleri arasında istatistiksel olarak anlamlı ve pozitif yönde ilişkilere (sanal tolerans, $r=0,185$; sanal iletişim, $r=0,363$; sanal problem, $r=0,448$; sanal bilgi, $r=0,173)$ rastlanmıştır $(p<0,01)$. Buna göre sosyal medya bağımlıık faktörleri arttıkça oyun oynama bozukluğunun da artacağı söylenebilir. Mutluluk ve sosyal medya bağımlılığı faktörlerinden sanal bilgi arasında istatistiksel olarak anlamlı ilişkiye rastlanmamıştır ( $p>0,05)$. Diğer sosyal medya bağımlılı̆ı faktörleri ile mutluluk arasında negatif yönlü ve oldukça zayıf ilişkilere (sanal tolerans, $r=-$ 0,122; sanal iletişim, $r=-0,166$; sanal problem, $r=-0,152)$ rastlanmıştır $(p<0,01)$.

Tablo 4. Sosyal medya bağımlılık faktörleri ile korelasyon analizi sonuçları

\begin{tabular}{|c|c|c|c|c|c|}
\hline & & $\begin{array}{c}\text { Sanal } \\
\text { Tolerans }\end{array}$ & $\begin{array}{l}\text { Sanal } \\
\text { Iletişim }\end{array}$ & $\begin{array}{l}\text { Sanal } \\
\text { Problem }\end{array}$ & $\begin{array}{c}\text { Sanal } \\
\text { Bilgi }\end{array}$ \\
\hline \multirow{2}{*}{ Mobil Bağımlılık } & Pearson Korrelasyon & $0,716^{\star \star}$ & $0,685^{\star \star}$ & $0,729^{\star \star}$ & $0,535^{\star \star}$ \\
\hline & Sig. (2-tailed) & 0,000 & 0,000 & 0,000 & 0,000 \\
\hline \multirow[t]{2}{*}{ FoMo } & Pearson Korrelasyon & $0,530^{\star \star}$ & $0,516^{\star \star}$ & $0,589^{\star \star}$ & $0,580^{\star *}$ \\
\hline & Sig. (2-tailed) & 0,000 & 0,000 & 0,000 & 0,000 \\
\hline \multirow[t]{2}{*}{ Oyun Oynama Bozukluğu } & Pearson Korrelasyon & $0,185^{\star \star}$ & $0,363^{\star \star}$ & $0,448^{* *}$ & $0,173^{\star *}$ \\
\hline & Sig. (2-tailed) & 0,006 & 0,000 & 0,000 & 0,009 \\
\hline \multirow[t]{2}{*}{ Mutluluk } & Pearson Korrelasyon & $-0,122^{\star \star}$ & $-0,166^{\star \star}$ & $-0,152^{\star *}$ & 0,060 \\
\hline & Sig. (2-tailed) & 0,009 & 0,000 & 0,001 & 0,197 \\
\hline
\end{tabular}

Tablo 5'te kişilik faktörleri ile mobil bağımlılık, oyun oynama bozukluğu, FoMo ve mutluluk arasındaki korelasyon değerleri verilmektedir. Mutluluk ile kişilik faktörleri arasında istatistiksel olarak anlamlı pozitif yönde ilişkiler (dışadönüklük, $r=0,402$; açık fikirlilik, $r=0,183$; yumuşak başlılk, $r=0,237$; dürüstlük, $r=0,341)$ tespit edilmiştir $(p<0,01)$. Ancak mutluluk ile nevrotik kişilik arasında negatif yönlü zayıf bir ilişki tespit edilmiştir $(r=-0,279 ; \quad p<0,01)$. Literatürde kişilik ve mutluluk arasındaki ilişki uzun yıllardır araştııımaktadır (69). Farklı kültürlerde; kişilik faktörleri ile internet ve Facebook bağımılı̆ğının ilişkili olduğunu vurgulayan araştırmalar literatürde mevcuttur (70).

Tablo 5. Kişilik faktörleri ile korelasyon analizi sonuçları

\begin{tabular}{|c|c|c|c|c|c|c|}
\hline & & Nevrotiklik & Dişadönüklük & $\begin{array}{l}\text { Açık } \\
\text { fikirllilk }\end{array}$ & $\begin{array}{c}\text { Yumuşak } \\
\text { başılllk }\end{array}$ & Dürüstlük \\
\hline \multirow[t]{2}{*}{ Mutluluk } & Pearson Korrelasyon & $-0,279^{\star \star}$ & $0,402^{\star \star}$ & $0,183^{\star \star}$ & $0,237^{\star \star}$ & $0,341^{\star \star}$ \\
\hline & Sig. (2-tailed) & 0,000 & 0,000 & 0,000 & 0,000 & 0,000 \\
\hline \multirow[t]{2}{*}{ FoMo } & Pearson Korrelasyon & $0,318^{\star \star}$ & $-0,021$ & $-0,004$ & 0,042 & $-0,058$ \\
\hline & Sig. (2-tailed) & 0,000 & 0,637 & 0,925 & 0,355 & 0,198 \\
\hline \multirow{2}{*}{$\begin{array}{l}\text { Mobil } \\
\text { Bağımlılık }\end{array}$} & Pearson Korrelasyon & $0,322^{\star \star}$ & 0,019 & $-0,045$ & $0,206^{\star \star}$ & $-0,201$ \\
\hline & Sig. (2-tailed) & 0,000 & 0,676 & 0,316 & 0,000 & 0,000 \\
\hline \multirow{2}{*}{$\begin{array}{l}\text { Oyun Oynama } \\
\text { Bozukluğu }\end{array}$} & Pearson Korrelasyon & 0,008 & $-0,128$ & $-0,078$ & $-0,217^{\star \star}$ & $-0,231^{\star \star}$ \\
\hline & Sig. (2-tailed) & 0,906 & 0,055 & 0,243 & 0,001 & 0,001 \\
\hline
\end{tabular}

* * Korelasyon 0,01 düzeyinde anlamlı. Sig.(2-uçlu). * Korelasyon 0,05 düzeyinde anlamlı. Sig.(2-uçlu).

Araştırma sonucumuza göre, mobil bağımlılık ile kişilik faktörleri arasında istatistiksel olarak anlamlı ilişkiler (nevrotiklik, $r=0,322$; yumuşak başlılık, $r=0,206$; dürüstlük, $r=-0,201)$ tespit edilmiştir $(p<0,01)$. Ancak 
mobil bağımlılık ile kişilik faktörlerinden dışadönüklük ve açık fikirlilik arasında anlamlı ilişki yoktur $(p>0,05)$. Oyun oynama bozukluğu ile kişilik faktörleri arasında istatistiksel olarak anlamlı negatif yönlü ilişkiler (yumuşak başllık, $r=-0,217$; dürüstlük, $r=-0,231)$ bulunmuştur $(p<0,01)$. Ancak oyun oynama bozukluğu ile nevrotiklik, dışadönüklük ve açık fikirlilik arasında anlamlı bir farklılık yoktur $(p>0,05)$. FoMo ile kişilik faktörleri arasında sadece nevrotiklik alt boyutu ile pozitif yönde nispeten zayıf bir ilişki tespit edilmiştir $(r=0,318 ; p<0,01)$. Diğer kişilik özellikleri ile FoMo arasında anlamlı bir ilişki tespit edilmemiştir ( $>0,05)$.

Tablo 6. Kişilik faktörleri ile sosyal medya bağımlılığı korelasyon analizi sonuçları

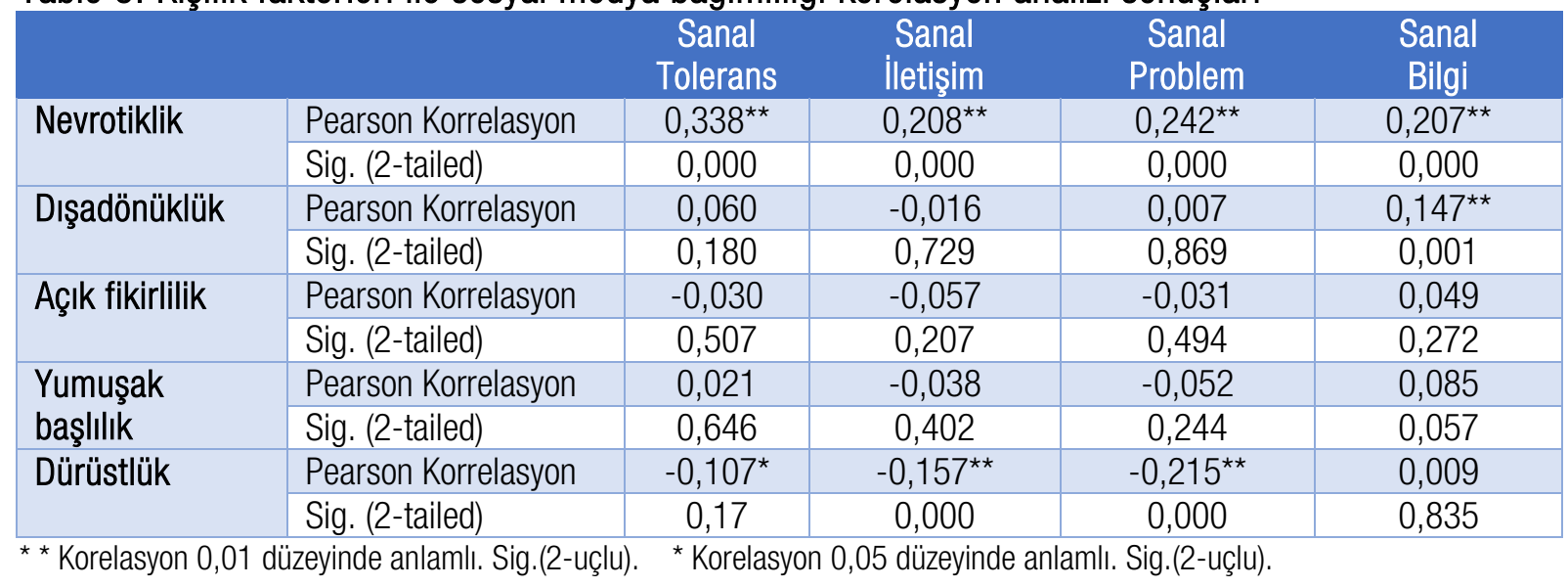

Tablo 7. Diğer değişkenler arasındaki korelasyon analizi sonuçları

\begin{tabular}{|c|c|c|c|c|}
\hline & & Mutluluk & $\begin{array}{l}\text { Oyun Oynama } \\
\text { Bozukluğu }\end{array}$ & $\begin{array}{c}\text { Mobil } \\
\text { Bağımlllık }\end{array}$ \\
\hline \multirow{2}{*}{$\begin{array}{l}\text { Oyun Oynama } \\
\text { Bozukluğu }\end{array}$} & Pearson Korrelasyon & $-0,147^{\star}$ & & \\
\hline & Sig. (2-tailed) & 0,035 & 1 & \\
\hline \multirow[t]{2}{*}{ Mobil Bağımlılık } & Pearson Korrelasyon & $-0,172^{\star \star}$ & $0,269^{\star \star}$ & \\
\hline & Sig. (2-tailed) & 0,000 & 0,000 & 1 \\
\hline \multirow[t]{2}{*}{ FoMo } & Pearson Korrelasyon & $-0,149^{\star \star}$ & $0,249^{* *}$ & $0,628^{\star \star}$ \\
\hline & Sig. (2-tailed) & 0,001 & 0,000 & 0,000 \\
\hline
\end{tabular}

Tablo 6'da kişilik faktörleri ile sosyal medya bağımlılı̆ı arasındaki korelasyon değerleri verilmektedir. Kişilik alt faktörlerinden nevrotiklik boyutu ile sosyal medya bağımlılığı arasında istatistiksel olarak anlamlı ve pozitif yönlü ilişkiler (sanal tolerans, $r=0,338$; sanal iletişim, $r=0,208$; sanal problem, $r=0,242$; sanal bilgi, $r=0,207)$ tespit edilmiştir $(p<0,01)$. Kişilik alt faktörlerinden dürüstlük boyutu ile sosyal medya bağımlılığı arasında istatistiksel olarak anlamlı ve negatif yönlü ilişkiler (sanal iletişim, $r=-0,157$; sanal problem, $r=-$ $0,215)$ tespit edilmiştir $(p<0,01)$. Dürüstlük boyutu ile sanal tolerans ve sanal bilgi alt boyutları arasında istatistiksel olarak anlamlı bir ilişki bulunmamıştır $(p>0,05)$. Kişilik alt faktörlerinden dışadönüklük boyutu ile sosyal medya bağımlılı̆ı alt faktörlerinden sadece sanal bilgi arasında istatistiksel olarak anlamlı ancak oldukça zayıf pozitif yönde ilişki tespit edilmiştir $(r=0,147 ; p<0,01)$. Diğer sosyal medya bağımlılığı alt faktörleri ile istatistiksel olarak anlamlı bir ilişki bulunmamıştır $(p>0,05)$. Kişilik alt faktörlerinden açık fikirlilik ve yumuşak başııık boyutları ile sosyal medya bağımlıığı arasında istatistiksel olarak anlamlı bir ilişkiler bulunmamıştır ( $p>0,05)$.

Tablo 8. Hipotezlere ait faktörler ve değerlendirme sonuçları

\begin{tabular}{|c|c|c|c|}
\hline Hipotez & Faktör & Illişki Durumu & Sonuç \\
\hline & $\begin{array}{c}\text { Mobil bağımlılık } \\
\rho \\
\text { Nevrotiklik/yumușak basilıı/dürüstlük }\end{array}$ & Negatif ilişki & Ret \\
\hline & $\begin{array}{c}\text { Mobil bağımlılık } \\
\rho\end{array}$ & Illişki yok & Kabul \\
\hline
\end{tabular}




\begin{tabular}{|c|c|c|c|}
\hline \multirow{7}{*}{ HO } & Dışadönüklük/Açık fikirlilik & & \\
\hline & $\begin{array}{l}\text { Oyun oynama bozukluğu } \\
\rho \\
\text { Yumuşak başl|lık/Dürüstlük }\end{array}$ & Pozitif ilişki & Ret \\
\hline & $\begin{array}{c}\text { Oyun oynama bozukluğu } \\
\rho \\
\text { Nevrotiklik/Dışadönüklük/Açı fikirlilik }\end{array}$ & Illişki yok & Kabul \\
\hline & $\begin{array}{l}\text { FoMo } \\
\rho \\
\text { Nevrotiklik }\end{array}$ & Pozitif ilişki & Ret \\
\hline & $\begin{array}{c}\text { FoMo } \\
\rho \\
\text { Dışadönüklük/Açık fikirlilik/Yumuşak başl|l|k/Dürüstlük }\end{array}$ & İlişki yok & Kabul \\
\hline & $\begin{array}{c}\text { Mutluluk } \\
\rho \\
\text { Dışadönüklük/Açık fikirlilik/Yumuşak başı|lık/Dürüstlük }\end{array}$ & Pozitif ilişki & Ret \\
\hline & $\begin{array}{c}\text { Mutluluk } \\
\rho \\
\text { Nevrotiklik }\end{array}$ & Negatif ilişki & Ret \\
\hline \multirow{5}{*}{$\mathrm{H} 1$} & $\begin{array}{c}\text { Mobil bağımlılık } \\
\rho \\
\text { Sanal tolerans/Sanal iletişim/Sanal problem/Sanal bilgi }\end{array}$ & Pozitif ilişki & Ret \\
\hline & $\begin{array}{c}\text { Oyun oynama bozukluğu } \\
\rho \\
\text { Sanal tolerans/Sanal iletişim/Sanal problem/Sanal bilgi }\end{array}$ & Pozitif ilişki & Ret \\
\hline & $\begin{array}{c}\text { FoMo } \\
\rho \\
\text { Sanal tolerans/Sanal iletişim/Sanal problem/Sanal bilgi }\end{array}$ & Pozitif ilişki & Ret \\
\hline & $\begin{array}{c}\text { Mutluluk } \\
\rho \\
\text { Sanal tolerans/Sanal iletişim/Sanal problem }\end{array}$ & Negatif ilişki & Ret \\
\hline & $\begin{array}{l}\text { Mutluluk } \\
\rho \\
\text { Sanal bilgi }\end{array}$ & İlişki yok & Kabul \\
\hline \multirow{7}{*}{$\mathrm{H} 2$} & $\begin{array}{c}\text { Nevrotiklik } \\
\rho \\
\text { Sanal tolerans/Sanal iletişim/Sanal problem/Sanal bilgi }\end{array}$ & Pozitif ilişki & Ret \\
\hline & $\begin{array}{c}\text { Dişadönüklük } \\
\rho \\
\text { Sanal bilgi }\end{array}$ & Negatif ilişki & Ret \\
\hline & $\begin{array}{c}\text { Dişadönüklük } \\
\rho \\
\text { Sanal tolerans/Sanal iletişim/Sanal problem }\end{array}$ & Illişki yok & Kabul \\
\hline & $\begin{array}{c}\text { Dürüstlükk } \\
\rho \\
\text { Sanal iletişim/Sanal problem }\end{array}$ & Negatif ilişki & Ret \\
\hline & $\begin{array}{c}\text { Dürüstlük } \\
\rho \\
\text { Sanal tolerans/Sanal bilgi }\end{array}$ & İlişki yok & Kabul \\
\hline & $\begin{array}{c}\text { Açık fikirlilik } \\
\rho \\
\text { Sanal tolerans/Sanal iletişim/Sanal problem/Sanal bilgi }\end{array}$ & Illişki yok & Kabul \\
\hline & $\begin{array}{c}\text { Yumuşak başıllık } \\
\rho\end{array}$ & Illişki yok & Kabul \\
\hline
\end{tabular}




\begin{tabular}{|c|c|c|c|}
\hline & Sanal tolerans/Sanal iletişim/Sanal problem/Sanal bilgi & & \\
\hline \multirow{6}{*}{ H3 } & $\begin{array}{c}\text { Oyun oynama bozukluğu } \\
\rho \\
\text { Mobil bağımlılık }\end{array}$ & Pozitif ilişki & Ret \\
\hline & $\begin{array}{c}\text { Oyun oynama bozukluğu } \\
\rho \\
\text { FoMo }\end{array}$ & Pozitif ilişki & Ret \\
\hline & $\begin{array}{c}\text { Oyun oynama bozukluğu } \\
\rho \\
\text { Mutluluk }\end{array}$ & Negatif ilişki & Ret \\
\hline & $\begin{array}{c}\text { Mobil bağımllık } \\
\rho \\
\text { FoMo }\end{array}$ & Pozitif ilişki & Ret \\
\hline & $\begin{array}{c}\text { Mobil bağımllık } \\
\rho \\
\text { Mutluluk }\end{array}$ & Negatif ilişki & Ret \\
\hline & $\begin{array}{c}\text { FoMo } \\
\rho \\
\text { Mutluluk }\end{array}$ & Negatif ilişki & Ret \\
\hline
\end{tabular}

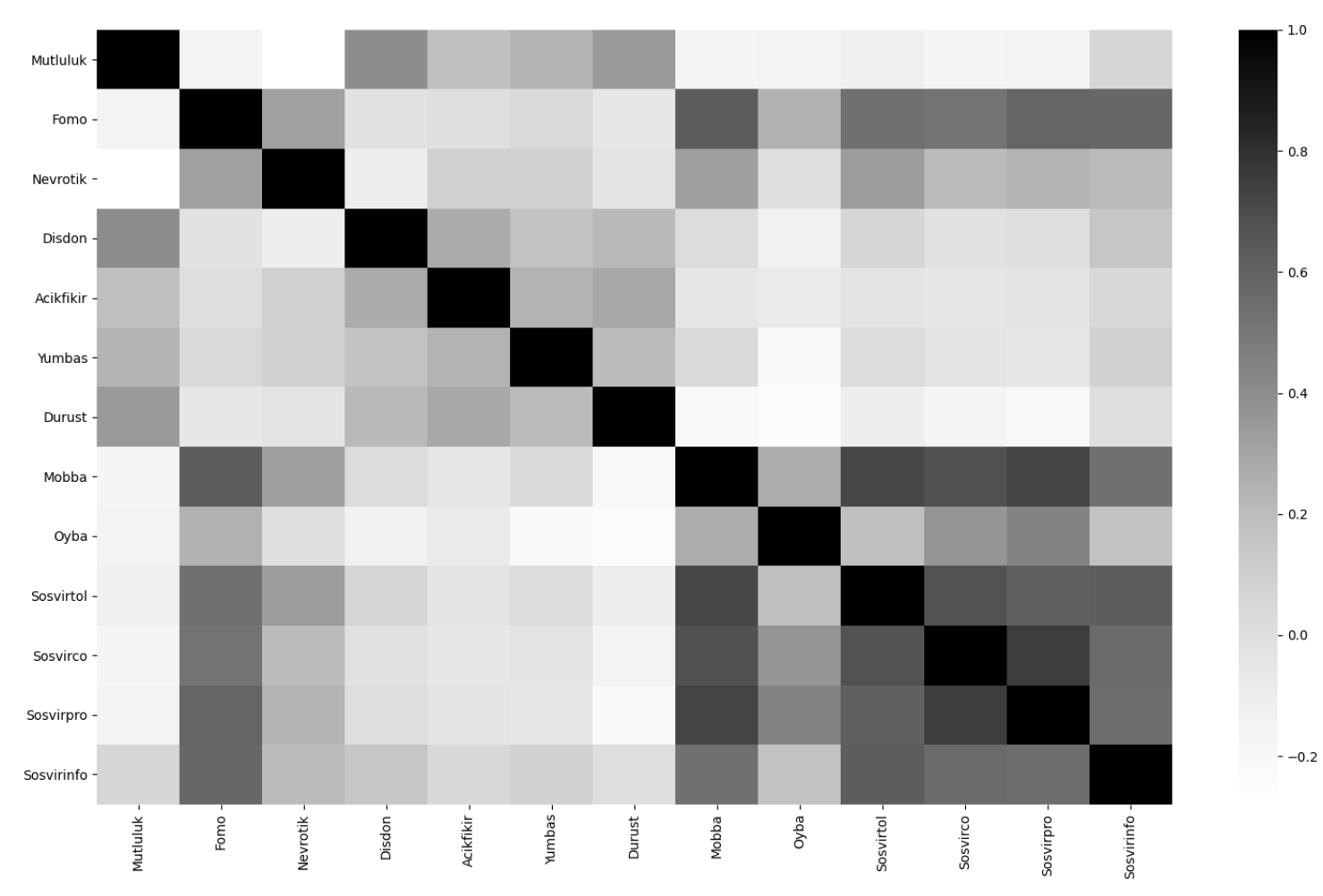

\section{Şekil 2. İlişkiler korelasyon matrisi}

Tablo 7'de mobil bağımlılık, oyun oynama bozukluğu, FoMo ve mutluluk arasındaki korelasyon değerleri verilmektedir. Oyun oynama bozukluğu ile mutluluk $(r=-0,147)$, mobil bağımlılık $(r=-0,172)$ ve FoMo $(r=-$ 0,149 ) değişkenleri arasında ise istatistiksel olarak anlamlı ancak oldukça zayıf negatif yönde ilişkiler tespit edilmiştir. Bu sonuçlara göre oyun oynama bozukluğu, mobil bağımlılık ve FoMo arttıkça mutluluk seviyesinin azalacağı söylenebilir. Oyun oynama bozukluğu ile mobil bağımlıık $(r=0,269)$ ve FoMo $(r=0,249)$ arasında da pozitif yönde nispeten zayıf ilişkiler tespit edilmiştir. Bu sonuçlara göre oyun oynama 
bozukluğu arttıkça mobil bağımlılık ve FoMo'nun da artacağı söylenebilir. Mobil bağımlılık ve FoMo $(r=0,628)$ arasında da istatistiksel olarak anlamlı pozitif yönde nispeten güçlü bir ilişki tespit edilmiştir. Bu sonuca göre mobil bağımlıık arttıkça FoMo'nun da artacağı söylenebilir.

Hipotezlere ait kurulan ilişki kümeleri Tablo 8'de gösterildiği gibidir. x, y, z ve t parametrelerinden oluşan faktörler ikili ele alınarak $\mathrm{H} 0, \mathrm{H} 1, \mathrm{H} 2$ ve $\mathrm{H} 3$ hipotezlerini oluşturur. Her bir hipoteze ait yapılan korelasyon analizleri sonrasında tespit edilen ilişkilerin yönü ve sonuçta kabul ya da ret durumları Tablo 8'de gösterildiği gibidir.

Şekil 2'de değişkenlerin korelasyon sonuçlarının tamamını birlikte gösteren korelasyon matrisi görsel olarak sunulmaktadır. Şekil 2'ye göre beyaz renkten siyah tonlu renklere gidildikçe korelasyon ilişkisi negatiften pozitif değere geçiş yapmaktadır. Siyah renk en yüksek korelasyonu yani 1 değerini işaret eder. Değişkenler arasındaki tüm ilişkiler toplu olarak görselleştirilmiştir.

\section{Tartışma}

Bu araştırma sosyal medya bağımlılığı, akılı telefon bağımlıı̆ı, oyun oynama bozukluğu ile beş faktör kişilik özellikleri, FoMo ve mutluluk arasındaki ilişkiyi keşfetmek amacıyla gerçekleştirilmiştir. Çalışmada araştırıan ilişkiler, her bir ölçek ve varsa alt boyutlarına ait geliştirilen $\mathrm{H} 0, \mathrm{H} 1, \mathrm{H} 2$ ve $\mathrm{H} 3$ hipotezleri çerçevesinde araştııımıştır. H0, H1, H2 ve H3 hipotezlerinden yalnızca H3 hipotezinde bakılan her bir ilişki kümesi reddedilmiştir. H0, H1 ve H2 hipotezlerinde kabul edilen ilişki kümeleri mevcuttur.

Araştırma sonucunda mobil bağımlılık, oyun oynama bozukluğu ve FoMo ile sosyal medya bağımlıı̆̆ı faktörleri arasında anlamlı ilişkiler tespit edilmiştir. Mutluluk ile sosyal medya bağımlılı̆ının faktörleri sanal tolerans, sanal iletişim ve sanal problem ile anlamlı, negatif yönlü zayıf ilișki mevcuttur. Sanal bilgi faktörü ile mutluluk düzeyi arasında anlamlı bir ilişki yoktur. Kişilik faktörlerinden dışadönüklük ve açık fikirlilik ile mobil bağımlıık arasında anlamlı bir ilişki bulunamazken, nevrotiklik, yumuşak başlılık ve dürüstlük ile mobil bağımlılık arasında anlamlı ilişki tespit edilmiştir. Oyun oynama bozukluğu ile nevrotiklik, dışadönüklük ve açık fikirlilik arasında anlamlı bir farklılık bulunmazken, yumuşak başıllık ve dürüstlük arasında anlamlı bir ilişki mevuttur. Kişilik faktörlerinden nevrotiklik ile sosyal medya bağımlı̆ı̆ı tüm alt faktörleri arasında anlamlı bir ilişki bulunmuştur. Kişilik faktörlerinden dürüstlük ile sosyal medya bağımlılı̆ı faktörlerinden sanal iletişim ve sanal problem arasında anlamlı bir ilişki bulunmuştur. Kişilik faktörlerinden dışa dönüklük, açık fikirlilik ve yumuşak başlıık ile sosyal medya bağımlıı̆ı faktörleri arasında anlamlı bir ilişki tespit edilmemiştir. FoMo ile sadece nevrotiklik faktörü arasında pozitif ilişki tespit edilmiştir. Mutluluk ile kişilik faktörleri arasında sadece nevrotiklik alt faktörü ile negatif ilişki tespit edilmişsir. Diğer dört kişilik faktörü ile mutluluk arasında anlamlı pozitif yönlü ilişki vardır. Nevrotiklik özelliği FoMo'yu artıııı etkiye sahipken, mutluluğu azaltıcı etkiye sahip olduğu söylenebilir.

Son yıllarda DiB ile ilgili bireylerin mutluluk ve iyi olma arasındaki ilişkileri inceleyen sınırlı sayıda araştırma olduğu (71-75) görülmektedir. Sosyal ağların bireylerin sosyal refah düzeylerine etkisi, sosyal medya kullanımının bireylerin subjektif mutluluk düzeylerine nasıl etki gösterdiği araştırma konusudur $(76,77)$.

Gelişmeleri kaçırma korkusu esasen dijital bağımlılığın getirdiği günümüz sorunlarındandır. Bireylerde görülen FoMo ve sosyal medya kullanımı arasındaki ilişkiyi araştıran çalışmalar son yıllarda artış göstermiştir $(48,52,53,78-82)$. Ayrıca FoMo ile beş faktör kişilik (78), mutluluk (83) ve oyun oynama bozukluğu (84) arasındaki ilişkileri araştıran çalışmalar mevcuttur. Ülkemizde FoMo kavramı ile ilgili çalışmaların sayısı oldukça kısıtıdır. (57). Bağımlılık kavramlarında özellikle davranış ve psikolojik faktörlerin araştırılması oldukça önemlidir.

Yapılan çalışmalar incelendiğinde çalışmamızdan farklı olarak, DiB araştırmalarında Dilci tarafından geliştirilen Dijital Bağımlılık Ölçeği'ni (20) kullanan çalışmalar mevcuttur. Her bir çalışmanın örneklem kümesi farklı yaş gruplarını araştırmaktadır. DiB ile cinsiyet, aile gelir durumu, sınıf düzeyi gibi sosyal kavramların ilişkisi araştııımışıı (21-23). Diğer çalışmalardan farklı olarak DiB kavramı kavramsal çerçevede ele alınmış ve DiB'i etkilediği düşünülen mutluluk, kişilik ve FoMo gibi kavramlar bütünüyle ele 
alınmıştır. Oyun bağımlılığı kavramı ülkemizde üzerinde en çok araştırma yapılan bağımlılık türlerinden birisi haline gelmiştir. Çalışmalarda, farkı yaş gruplarında görülen etkiler ve sosyal değişkenlerle olan ilişkiler üzerinde durulmuştur (27-30). Ayrıca oyun bağımlıı̆ıı ile ilgili psikolojik etkenlerin (31) yanı sıra kişilik ve davranış etkileri üzerinde araştırmalar mevcuttur (32).

Elde ettiğimiz sonuçlara benzer şekilde; dijital oyun bağımlılığı ile akıllı telefon bağımlılı̆ı arasındaki iliş̧kiyi araştıran çalışmanın sonucunda iki değişken arasında anlamlı bir ilişki bulunmuştur (42). Bir diğer çalışmada akıllı telefon bağımlılığı ile mutluluk arasındaki ilişki incelenmiş ve negatif yönlü, anlamlı bir ilişki tespit edilmiştir (75). Sheldon vd., yaptıkları çalışmada FoMo ile sosyal medya bağımlılığı arasında anlamlı bir ilişki tespit etmiş ve sosyal medya uygulamalarından Snapchat adlı uygulamanın en belirleyici etken olduğunu belirlemişlerdir (79).

Çalışmamızın, benzer alanda yapılan araştırmalara önemli bir katkı sağladığı düşünülmektedir. Sosyal medya bağımlılı̆ı, akıllı telefon bağımlı̆ı̆̆ ile oyun oynama bozukluğu; kişilik, FoMo ve mutluluk kavramlarının bütüncül olarak incelenmesi araştırmanın farklı yanını ortaya koymaktadır. Yanı sıra çalışmanın kısıtları bulunmaktadır. Örneklemin sadece üniversite öğrencileri ve Erciyes Üniversitesi'nde okuyan öğrencilerden seçilmiş olmasıdır. Bu nedenle genel bir şablon ortaya konamaz. Farklı yaş gruplarında olan ve farklı il veya ülkelerde yaşayan insanlarla araştırmalar yapıldığında benzer ve farklı yanlar ortaya konulabilir.

Dijital bağımlılık kavramının küçük yaşlardan itibaren kontrol edilmesi oldukça önemlidir. Gelecek araşıırmalarda; elektronik cihazların ve sosyal ağların denetimli kullanımını amaçlayan; yazılım sistemlerinde pozitif tasarıma odaklanarak ve yazılım sistemlerine entegre edilebilecek makine öğrenimi yöntemleri tabanlı bir model önerisi geliştirilmesi planlanmaktadır.

\section{Teşekkür}

Bu araştırma, 116E676 numaralı Tübitak 1003 Öncelikli Alanlar Ar-Ge projesi olan "Mutlu proje: Sosyal Mutluluk Ölçen Bir Sosyo-Teknik Madenleme Sistemi" proje desteği ile TÜBITAK tarafından desteklenmiştir. Ayrıca Prof. Dr. Raian Ali'ye bilgi ve deneyimleri için teşekkürlerimizi sunarız.

\section{Kaynaklar}

1. Türkiye İstatistik Kurumu. Hanehalkı Bilişim Teknolojileri (BT) Kullanım Araştırması. https://data.tuik.gov.tr/Bulten/Index?p=Hanehalki-Bilisim-Teknolojileri-(BT)-Kullanim-Arastirmasi-2020-33679 (5 Şubat 2021'de ulaşוldı).

2. We Are Social, Hootsuite. Global Digital Reports. https://wearesocial.com/digital-2020 (5 Mart 2021'de ulaşıld).

3. UNICEF. Dijital Bir Dünyada Çocuklar: Dünya Çocuklarının Durumu. https://www.unicef.org/publications/files/SOWC_2017_ENG_WEB.pdf (5 Şubat 2021'de ulaşıldı).

4. Kahya Özyirmidokuz E, Akpınar Karakaş B. Dijital Bağımılıık ile Mücadelede Sosyal Bilişimin Rolü. Içinde: IIter K (ed) 5th International Management Information Systems Conference. IMISC, Ankara, 2018.

5. Alrobai AA. Engineering Social Networks to Combat Digital Addiction: The Case of Online Peer Groups. Doctoral Thesis, United Kingdom: Bournemouth University, Department of Philosophy, 2018.

6. Kesici A, Tunç NF. The development of the digital addiction scale for the university students: Reliability and validity study. Universal Journal of Educational Research 2018; 6(1): 91-98.

7. American Psychiatric Association: Diagnostic and Statistical Manual of Mental Disorders. 5. Baskı. Arlington, VA, American Psychiatric Association, 2013: 795-797.

8. Young KS. Internet addiction: The emergence of a new clinical disorder. CyberPsychology Behav 1998; 1(3): 237-244.

9. Almourad MB, McAlaney J, Skinner T, et al Defining digital addiction: Key features from the literature. Psihologija 2020; 53(3): 237-253.

10. Ali R. Digital Addiction Research. https://www.bournemouth.ac.uk/research/projects/digital-addiction-research (5 Şubat 2021'de ulaşıldı). 
11. Ali R, Jiang N, Phalp K, et al. The Emerging Requirement for Digital Addiction Labels. Içinde: Fricker SA, Schneider K (ed) REFSQ 2015: Requirements Engineering: Foundation for Software Quality . Springer Verlag, Essen, Germany, 2015: 198-213.

12. Alrobai A, McAlaney J, Phalp K, Ali R. Exploring the risk factors of interactive e-health interventions for digital addiction. International Journal of Sociotechnology and Knowledge Development 2016; 8(2): 1.

13. Alrobai A, McAlaney J, Phalp K, Ali R. Online Peer Groups as a Persuasive Tool to Combat Digital Addiction. Içinde: Meschtscherjakov A, De Ruyter B, Fuchsberger V, et al (ed) Persuasive Technology. Springer Verlag, Salzburg, Austria, 2016: 288-300.

14. Altuwairiqi M, Arden-Close E, Bolat E, et al. When People are Problematically Attached to Social Media: How Would the Design Matter? Içinde: Conference Proceedings - IEEE International Conference on Systems, Man and Cybernetics 2019: 4211-4218.

15. Alutaybi A, Mcalaney J, Arden-Close E, et al Fear of Missing Out (FoMO) as Really Lived: Five Classifications and one Ecology Psychological Factors of Cybersecurity. 6th International Conference on Behavioral, Economic and Socio-Cultural Computing (BESC). Beijing, China 2019: 1-6.

16. Cham S, Algashami A, Aldhayan M, et al. Digital Addiction: Negative Life Experiences and Potential for Technology-Assisted Solutions. Içinde: Advances in Intelligent Systems and Computing. Springer Verlag, 2019: 921-931.

17. McAlaney J, Aldhayan M, Almourad MB, et al. Predictors of Acceptance and Rejection of Online Peer Support Groups as a Digital Wellbeing Tool. Içinde: Advances in Intelligent Systems and Computing. Springer 2020: 95107.

18. Günüç S. İnternet bağımlıık ölçeğinin geliştirilmesi ve bazı demografik değişkenler ile internet bağımlı̆ğı arasındaki ilişkilerin incelenmesi. Yüksek Lisans Tezi, Van: Yüzüncü Yı Üniversitesi, Eğitim Programları ve Öğretimi Bilim Dall, 2009.

19. Bakır Ağyar B, Uzun B. Developing the social media addiction scale: Validity and reliability studies. Addicta: The Turkish Journal on Addictions 2018; 5(3): 507-525.

20. Dilci T. A study on validity and reliability of digital addiction scale for 19 years or older. Universal Journal of Educational Research 2019; 7(1): 32-39.

21. Dilci T, Arslan A, Ersoy M. 0-12 yaş aralığındaki çocukların dijital bağımlılık düzeylerinin çeşitli değiş̧kenlere göre belirlenmesi: Sivas ili örneklemi. Tarih Okulu Dergisi 2019; 12(38): 122-142.

22. Arslan A. Ortaöğretim öğrencilerinin dijital bağımlılık düzeylerinin çeşitli değişkenler açısından incelenmesi: Sivas ili örneği. Gazi University Journal of Science 2019; 5(2): 63-80.

23. Arslan A. Üniversite öğrencilerinin dijital bağımlılık düzeylerinin çeşitli değişkenler açısından incelenmesi. International e-Journal of Educational Studies 2020; 4(7): 27-41.

24. AvcI F, Er H. Investigation of teacher views on digital addiction and suggestions for solution. Language Teaching and Educational Research 2019; 2(2): 132-159.

25. Ertemel AV, Eroğlu Pektaş GÖ. Dijitalleşen dünyada tüketici davranışları açısından mobil teknoloji bağımlılığı: Üniversite öğrencileri üzerine nitel bir araştırma. Yıldız Sosyal Bilimler Enstitüsü Dergisi 2018; 2(2): 18-34.

26. Durmuş H, Günay 0 , Yıldı S, et al. Üniversite öğrencilerinde internet bağımlıı̆ı ve üniversite yaşamı boyunca değişimi. Anadolu Psikiyatri Derg 2018; 19(4): 383-389.

27. Göldağ B. Lise öğrencilerinin dijital oyun bağımlıllk düzeylerinin demografik özelliklerine göre incelenmesi. Yüzüncü Yıl Üniversitesi Eğitim Fakültesi Dergisi 2018; 15(1): 1287-1315.

28. Hazar K, Özpolat Z, Hazar Z. Ortaokul öğrencilerinin dijital oyun bağımlıı̆ı düzeylerinin çeşitli değişkenlere göre incelenmesi (Niğde ili örneği). SPORMETRE Beden Eğitimi ve Spor Bilimleri Dergisi 2020; 18(1): 225-234.

29. Oral AH, Arabacıoğlu T. Illkokul 4. sınıf öğrencilerinin dijital oyun bağımlılıklarının çeşitli değişkenler açısından incelenmesi. Trakya Eğitim Dergisi 2019; 9(1): 44-60.

30. Taylan HH, Topal M, Ayas T. Sakarya'daki lise öğrencilerinin dijital oyun oynama eğilimlerinin incelenmesi. Online Journal of Technology Addiction and Cyberbullying 2018; 5(1): 53-68.

31. Yalçın Irmak A, Erdoğan S. Ergen ve genç erişkinlerde dijital oyun bağımlıı̆ı: Güncel bir bakış. Ergen ve genç erişkinlerde dijital oyun bağımlılığ: güncel bir bakış. Turk Psikiyatri Derg 2016; 27(2): 128-137.

32. Yiğit Açıkgöz $F$, Yalman A. Dijital oyunların çocukların kişilik ve davranışları üzerinde etkisi: Gta 5 oyunu örneği. Akdeniz Üniversitesi Illetişim Fakültesi Dergisi 2018; Özel Sayı: 163-180.

33. Dursun A, Eraslan Çapan B. Ergenlerde dijital oyun bağımlıı̆̆ ve psikolojik intiyaçlar. İnönü Üniversitesi Eğitim Fakültesi Dergisi 2018; 19(2): 128-140.

34. Gökbulut B. Ortaokul öğrencilerinin akran zorbalığı ve dijital oyun bağımlılı̆ı arasındaki ilişki. Karaelmas Eğitim Bilimleri Dergisi 2020; 8: 89-100. 
35. Güvendi B, Tekkurşun Demir G, Keskin B. Ortaokul öğrencilerinde dijital oyun bağımlılığı ve saldırganlık. OPUS Uluslararası Toplum Araştırmaları Dergisi 2019; 11(18): 1194-1217.

36. Hazar Z, Hazar K, Gökyürek B, et al. Ortaokul öğrencilerinin oyunsallık, dijital oyun bağımllığı ve saldırganlık düzeyleri arasındaki ilişkinin çeşitli değişkenler açısından incelenmesi. Journal of Human Sciences 2017; 14(4): 4320-4332.

37. Yücel G, Şan Ș. Dijital oyunlarda bağımlılık ve șiddet: blue whale oyunu üzerinde bir inceleme. AJIT-e: Bilișim Teknolojileri Online Dergisi 2018; 9(32): 87-100.

38. Hazar Z. Spor yapan ve yapmayan çocukların dijital oyun bağımlıı̆̆ ile öz yeterlik inanç düzeyleri arasındaki ilişkinin incelenmesi. Journal of Human Sciences 2019; 16(1): 315-325.

39. Namlı S, Tekkurşun Demir G. The relationship between attitudes towards digital gaming and sports. Turkish Online Journal of Educational Technology 2020; 19(1): 40-52.

40. Savci M, Aysan F. Teknolojik bağımlılıklar ve sosyal bağlılı: internet bağımlıı̆ıı, sosyal medya bağımlılığı, dijital oyun bağımlıı̆̆ı ve akıllı telefon bağımlılığının sosyal bağ|lığı yordayıcı etkisi. Dusunen Adam 2017; 30(3): 202216.

41. Işık M, Kaptangil İ. Akıllı telefon bağımlıı̆ının sosyal medya kullanımı ve beş faktör kişilik özelliği ile ilişkisi: Üniversite öğrencileri üzerinden bir araştırma. İnsan ve Toplum Bilimleri Araştırmaları Dergisi 2018; 7(2): 695717.

42. Göymen R, Ayas T. Akıllı telefon bağımlılığı ve oyun bağımlıı̆ı arasındaki ilişkinin incelenmesi. Online Journal of Technology Addiction and Cyberbullying 2019; 6(2): 36-52.

43. Güney M, Taştepe T. Ergenlerde sosyal medya kullanımı ve sosyal medya bağımlıl̆ğ. Ankara Sağlık Bilimleri Dergisi 2020; 9(2): 183-190.

44. Koçak Ç, Yiğit T. Teknoloji bağımlıı̆ının bulanık mantık ile sınıflandırılması. Mühendislik Bilimleri ve Tasarım Dergisi 2020; 8(5): 126-132.

45. Beyens I, Frison E, Eggermont S. "I don't want to miss a thing": Adolescents' fear of missing out and its relationship to adolescents' social needs, Facebook use, and Facebook related stress. Comput Human Behav 2016; 64: 1-8.

46. Buglass SL, Binder JF, Betts LR, Underwood JDM. Motivators of online vulnerability: The impact of social network site use and fomo. Comput Human Behav 2017; 66: 248-255.

47. Przybylski AK, Murayama K, Dehaan CR, Gladwell V. Motivational, emotional, and behavioral correlates of fear of missing out. Comput Human Behav 2013; 29: 1841-1848.

48. Gannamani VS, Kumar A, Bandaru R, Fiaidhi J. Fear of missing out, social media engagement, smartphone addiction, and distraction: The role of mobile applications-based intervention. TechRxiv 2019; doi: 10.36227/techrxiv.12094140.v1.

49. Altuwairiqi M, Kostoulas T, Powell G, Ali R. Problematic attachment to social media: Lived experience and emotions. Içinde: Advances in Intelligent Systems and Computing. Springer Verlag, 2019: 795-805.

50. Alutaybi A, Al-Thani D, McAlaney J, Ali R. Combating fear of missing out (FoMO) on social media: The FoMO-r method. Int J Environ Res Public Health 2020; 17(17): 6128.

51. Elhai JD, Yang H, Fang J, et al. Depression and anxiety symptoms are related to problematic smartphone use severity in Chinese young adults: Fear of missing out as a mediator. Addict Behav 2020; 101: 105962.

52. Cargill M. The Relationship Between Social Media Addiction, Anxiety, the Fear of Missing Out, and Interpersonal Problems. Doctoral Thesis, Ohio: The University of Akron, Department of Philosophy, 2019.

53. Casale S, Rugai L, Fioravanti G. Exploring the role of positive metacognitions in explaining the association between the fear of missing out and social media addiction. Addict Behav 2018; 85: 83-87.

54. Kuss DJ, Griffiths MD. Online social networking and addiction-a review of the psychological literature. Int J Environ Res Public Health 2011; 8(9): 3528-3552.

55. Yoo K-H, Gretzel U. Influence of personality on travel-related consumer-generated media creation. Comput Human Behav 2011; 27(2): 609-621.

56. Uyar K. Perakende terapi. Business and Management Studies: An International Journal 2019; 7(1): 496-513.

57. Metin B, Pehlivan R, Tarhan N. Realiability and validity of Uskudar Fear Of Missing Out Scale. Journal of Neurobehavioral Sciences 2017; 4(2): 40-46.

58. Kwon M, Lee JY, Won WY, et al. Development and validation of a Smartphone Addiction Scale (SAS). PLoS One 2013; 8(2): e56936

59. Demirci K, Orhan H, Demirdas A, et al. Akıllı Telefon Bağımlı̆̆ğ Ölçeği'nin Türkçe formunun gençlerde geçerlilik ve güvenilirliği. Klinik Psikofarmakoloji Bülteni 2014; 24(3): 226-234.

60. Pontes HM, Griffiths MD. Measuring DSM-5 internet gaming disorder: Development and validation of a short psychometric scale. Comput Human Behav 2015; 45: 137-143. 
61. Arıcak 0, Dinç M, Yay M, Griffiths M. Adapting the short form of the Internet Gaming Disorder Scale into Turkish: Validity and reliability. Addicta: The Turkish Journal on Addictions 2018; 5(4): 615-636.

62. Şahin C. Social media addiction scale-student form: The reliability and validity study. The Turkish Online Journal of Educational Technology 2018; 17(1): 169-182.

63. Bagby RM, Parker JDA, Taylor GJ. The twenty-item Toronto Alexithymia scale-I. Item selection and crossvalidation of the factor structure. J Psychosom Res 1994; 38(1): 23-32.

64. Güleç H, Köse S, Güleç MY, et al. Reliability and factorial validity of the Turkish version of the 20-item Toronto alexithymia scale (TAS-20). Klinik Psikofarmakoloji Bülteni 2009; 19(3): 215-221.

65. Hills $P$, Argyle M. The Oxford Happiness Questionnaire: A compact scale for the measurement of psychological well-being. Pers Individ Dif 2020; 33(7): 1073-1082.

66. Tayfun D, Sapmaz F. Oxford Mutluluk Ölçeği Türkçe formunun psikometrik özelliklerinin üniversite öğrencilerinde incelenmesi. Dusunen Adam 2012; 25(4): 297-304.

67. Nunnaly JC. Psychometric Methods. In: Psychometric Methods. Springer, Dordrecht, New York, 2002: 97-126.

68. George D, Mallery P. SPSS for Windows Step by Step: A Simple Study Guide and Reference, 17.0 Update. Pearson, Boston, 2010.

69. Furnham A, Brewin CR. Personality and happiness. Pers Individ Dif 1990; 11: 1093-1096.

70. Błachnio A, Przepiorka A, Senol-Durak E, et al. The role of personality traits in Facebook and internet addictions: A study on Polish, Turkish, and Ukrainian samples. Comput Human Behav 2017; 68: 269-275.

71. Bluteau J, Bluteau P. Obsessive Consumption Disorder: Tackling the problem of handheld digital addiction. J Psychiatry 2020; 23(6): 1.

72. Sağlam M, Topsümer F. Dijital oyunlar ve öznel iyi oluş ilişkisi: Muğla sıtkı koçman üniversitesi örneği. Humanities Sciences 2019; 14(2): 31-50.

73. Mochón F. Happiness and technology: Special consideration of digital technology and internet. International Journal of Interactive Multimedia and Artificial Intelligence 2018; 5(3): 162-168.

74. Kahya Özyirmidokuz E, Stoica EA, Uyar K. Mutlu proje: Adaptif duygusal bir sosyo-teknik sistem yaklaşımı. Yönetim Bilişim Sistemleri Dergisi 2017; 3(2): 32-46.

75. Özteke Kozan Hi, Kavaklı M, Ak M, Kesici Ş. Akıllı telefon bağımlılı̆ı, genel aidiyet ve mutluluk arasındaki ilişkilerin yapısal eşitlik modellemesi ile incelenmesi. Klinik Psikiyatri Dergisi 2019; 22(4): 436-444.

76. Reer F, Tang WY, Quandt T. Psychosocial well-being and social media engagement: The mediating roles of social comparison orientation and fear of missing out. New Media \& Society 2019; 21(7): 1486-1505.

77. Chai HY, Niu GF, Lian SL, et al. Why social network site use fails to promote well-being? The roles of social overload and fear of missing out. Comput Human Behav 2019; 100: 85-92.

78. Rozgonjuk D, Sindermann C, Elhai JD, Montag C. Individual differences in Fear of Missing Out (FoM0): Age, gender, and the Big Five personality trait domains, facets, and items. Pers Individ Dif 2021; 171: 110546.

79. Sheldon P, Antony MG, Sykes B. Predictors of Problematic Social Media Use: Personality and life-position indicators. Psychol Rep 2021; $124: 1110-1133$.

80. Alam T. Millennials: Fear of Missing Out (FOMO) and social media engagement. SAGE Preprint. 2021; doi: 10.31124/advance.14046824.v1

81. Silva Santos IL, Pimentel CE, Mariano TE. Cyberstalking scale: Development and relations with gender, FOMO and social media engagement. Curr Psychol 2021; doi: 10.1007/s12144-021-01823-3.

82. Tandon A, Dhir A, Almugren I, et al. Fear of missing out (FoM0) among social media users: A systematic literature review, synthesis and framework for future research. Internet Res 2021; 31(3): 782-821.

83. Lee JA, Bright LF, Eastin MS. Fear of Missing Out and consumer happiness on Instagram: A serial mediation of social media influencer-related activities. Cyberpsychol Behav Soc Netw 2021; doi: 10.1089/cyber.2020.0431.

84. Elhai JD, McKay D, Yang $\mathrm{H}$, et al. Health anxiety related to problematic smartphone use and gaming disorder severity during COVID-19: Fear of missing out as a mediator. Hum Behav Emerg Technol 2021; 3(1): 137-146. 